dr hab. Agnieszka Merkisz - Guranowska, prof. nadzw. PP

Politechnika Poznańska

Instytut Pojazdów Szynowych „,TABOR”

mgr inz. Hanna Stawecka

Instytut Pojazdów Szynowych ,TABOR”

\title{
Recykling wagonów tramwajowych w Polsce
}

\begin{abstract}
$W$ artykule omówiono zagadnienia zwiqzane z recyklingiem wagonów tramwajowych. Mimo braku uregulowań prawnych zwiqzanych z zagospodarowaniem pojazdów szynowych, recykling taboru jest prowadzony głównie z uwagi na korzyści ekonomiczne. W artykule przedstawiono, skale zjawiska, regulacje prawne oraz czynniki i uwarunkowania wpływajace na skuteczność procesu recyklingu wagonów tramwajowych. Przedstawiono system recyklingu wagonów tramwajowych, $w$ tym proces demontażu, na przyktadzie przedsiębiorstwa Tramwaje Warszawskie Sp. z o.o., które jest największym polskim przewoźnikiem tramwajowym. Ponadto scharakteryzowano sieć recyklingu taboru ze wskazaniem miejsc przeprowadzania odzysku wagonów tramwajowych w Polsce.
\end{abstract}

\section{Wprowadzenie}

Obecnie recykling stał się nieodzownym elementem cyklu życia produktu, chociaż zagospodarowanie odpadów przyjazne środowiskowo zostało na stałe wprowadzone do praktyki gospodarczej dopiero $\mathrm{w}$ ostatnich dwudziestu latach. Pierwsze próby zastosowania metody kompleksowego recyklingu, w celu odzyskiwania możliwie jednorodnych surowców podjęto w krajach rozwiniętych, zarówno w Europie, jak i poza nia, w połowie lat siedemdziesiątych XX wieku. Sięgnięto po urządzenia, techniki i technologie stosowane $\mathrm{w}$ różnych dziedzinach gospodarki np. $\mathrm{w}$ górnictwie.

Przodującymi krajami na świecie pod względem segregacji i odzysku odpadów są Holandia, gdzie recyklingowi poddawane jest $63 \%$ odpadów, Niemcy $\mathrm{z}$ $56 \%$ wskaźnikiem oraz kraje skandynawskie z $40 \%$ $[13,32]$. W Polsce proces systemowej segregacji odpadów rozpoczął się dopiero pod koniec lat dziewięćdziesiatych XX wieku. Obecnie w Polsce recyklingowi poddawane jest około $15 \%$ wszystkich powstających odpadów [13, 32].

Rozwój gospodarczy, oprócz pozytywnych aspektów takich jak podnoszenie poziomu jakości życia społeczeństw, pociaga za sobą także negatywne skutki dla człowieka i środowiska naturalnego. Jednym $\mathrm{z}$ tych skutków są odpady generowane między innymi przez środki transportu zarówno na etapie produkcji, eksploatacji jak i wycofania z użytku. Sposobem na ograniczenie tego negatywnego wpływu stał odzysk, czyli gospodarcze wykorzystanie odpadów. Rosnąca świadomość ekologiczna we współczesnych społeczeństwach, wprowadzane regulacje prawne mające na celu ograniczanie ilości odpadów przeznaczonych do składowania, ale również korzyści ekonomiczne jakie można uzyskać z utylizacji zużytych produktów powodują, że tworzenie sieci recyklingu odpadów stało się ważnym problemem, szczególnie w krajach rozwiniętych.

Pojęcie recykling wywodzi się z języka angielskiego i jest jedną z metod ochrony środowiska, której głównym celem jest ograniczenie zużycia surowców naturalnych oraz zmniejszenie ilości odpadów. Recykling oznacza ponowne przetwarzane odpadów na produkty, materiały lub substancje wykorzystywane w pierwotnym celu lub innych celach, z wyjattkiem odzysku energii [28]. Nadrzędną zasadą recyklingu jest w jak największym stopniu ponowne wykorzystanie użytych do produkcji materiałów przy jednoczesnym ograniczaniu nakładów niezbędnych do ich przetworzenia i odzysku.

Działaniom związanym z recyklingiem powinny podlegać wszystkie środki transportu, chociaż w praktyce najszerszy zakres odzysku i recyklingu dotyczy pojazdów samochodowych o dopuszczalnej masie całkowitej do 3,5 t. Nie znaczy to jednak, że w przypadku innych środków transportu nie prowadzi się takich działań. Przytoczyć można szereg przykładów recyklingu pojazdów szynowych, ale również statków powietrznych czy morskich.

\section{Uregulowania prawne}

Z uwagi na to, że ilość odpadów generowanych przez pojazdy szynowe, w tym wagony tramwajowe jest znacznie mniejszym problemem niż odpady z samochodów wycofanych $z$ eksploatacji, zarówno władze międzynarodowe, jak i poszczególnych państw do 
chwili obecnej nie uregulowały kompleksowo problematyki recyklingu pojazdów szynowych. Zagadnienia recyklingu środków transportu zostały uregulowane wyłącznie $\mathrm{w}$ przypadku pojazdów samochodowych i to tylko samochodów osobowych i dostawczych o masie całkowitej do 3,5 tony.

Jedynym dokumentem odnoszącym się do recyklingu pojazdów szynowych jest Kodeks (Karta) Międzynarodowego Związku Kolei (UIC - International Union of Railways). Karta nr 345 E zatytułowana „Specyfikacje środowiskowe dla nowych pojazdów szynowych" [5] została wydana w czerwcu 2006 roku. Dokument ten odnosi się do aspektów ekoprojektowania i uwzględnienia na etapie projektowania oddziaływań środowiskowych generowanych przez pojazdy szynowe w trakcie całego cyklu życia. Karta UIC 345 E określa, że już na początku projektowania pojazdu szynowego producenci powinni stosować metodę REPID 2003, umożliwiającą uwzględnienie w procesie konstruowania takich aspektów jak: recykling materiałowy, efektywne zarządzanie zasobami, unikanie powstawania odpadów oraz uzyskiwanie jak najwyższego poziomu odzysku.

Pomimo, że nie wprowadzono regulacji prawnych dotyczących odzysku wycofanych pojazdów szynowych, producenci i uczestnicy rynku przewozów kolejowych powinni wspierać europejską politykę w zakresie zagospodarowania odpadów. Jako punkty odniesienia powinny posłużyć standardy przemysłu samochodowego. Jednym z postulatów jest uwzględnianie w projektowaniu nowych pojazdów szynowych wymaganych poziomów odzysku i recyklingu określonych w Dyrektywie 2000/53/EC Parlamentu Europejskiego i Rady z dnia 18 września 2000 roku w sprawie pojazdów wycofanych z eksploatacji [2]. Zgodnie $\mathrm{z}$ wspomniana dyrektywą wymagany poziom odzysku powinien wynieść $85 \%$ do 2015 roku, a od 2015 roku $95 \%$ masy pojazdu. Ponadto do 2015 roku maksymalnie $5 \%$ masy może zostać poddane odzyskowi energii (spalenie w celu wykorzystania energii zawartej w materiałach), a $80 \%$ masy powinno zostać poddane recyklingowi (recykling produktowy lub materiałowy). Od 2015 roku wskaźnik recyklingu zostanie podwyższony do $85 \%$, a maksymalnie $10 \%$ masy będzie mogło zostać spalone w celu odzysku energii.

W karcie 345 E postuluje się także wykorzystanie metody obliczeniowej zdolności pojazdów drogowych do recyklingu i odzysku, zawartej $\mathrm{w}$ normie ISO 22628, jako wzoru dla sektora kolejowego.

W nawiązaniu do powyższego w 2011 roku Europejskie Stowarzyszenie Przemysłu Kolejowego (UNIFE - Association of the European Rail Industry) zrzeszające producentów reprezentujących $80 \%$ rynku kolejowego zainicjowało utworzenie jednolitych wytycznych recyklingu dla środków transportu kolejowego [33]. Podstawą tych wytycznych jest wspomniana norma ISO 22628 przeznaczona dla sektora samochodowego, jednak jej uregulowania zostały dostosowane do specyfiki taboru kolejowego. Ma ona docelowo stanowić podstawę dopuszczenia taboru do ruchu w Unii Europejskiej.

W wielu krajach europejskich regulacje w zakresie wymagań technicznych przy projektowaniu, homologacji, eksploatacji i wycofaniu z eksploatacji tramwajów uregulowane są odrębnymi krajowymi przepisami.

Takie rozwiązanie dopuszcza Dyrektywa 2004/49/WE Parlamentu Europejskiego i Rady z dnia 29 kwietnia 2004 r. w sprawie bezpieczeństwa kolei wspólnotowych oraz zmieniająca dyrektywę Rady 95/18/WE w sprawie przyznawania licencji przedsiębiorstwom kolejowym, oraz dyrektywę 2001/14/WE w sprawie alokacji zdolności przepustowej infrastruktury kolejowej i pobierania opłat za użytkowanie infrastruktury kolejowej oraz certyfikację w zakresie bezpieczeństwa (Dyrektywa w sprawie bezpieczeństwa kolei) [1].

Dyrektywa ta stwierdza, że tramwaje są też często przedmiotem prawodawstwa dotyczaceego bezpieczeństwa $\mathrm{w}$ transporcie drogowym i w związku z tym nie mogą być $w$ pełni ujęte $w$ przepisach dotyczących bezpieczeństwa kolei. Również na podstawie tej dyrektywy metro i inne lekkie systemy transportu szynowego w wielu państwach członkowskich podlegaja przepisom krajowym lub regionalnym.

W niektórych państwach UE krajowe uregulowania w sposób pośredni wymuszają na producentach taboru kolejowego uwzględnianie problemu recyklingu poprzez ujęcie tego zagadnienia $\mathrm{w}$ dokumentacji technicznej pojazdu. Na przykład w Polsce, Rozporządzenie Ministra Infrastruktury z dnia 12 października 2005 r. w sprawie ogólnych warunków technicznych eksploatacji pojazdów kolejowych [20] nakłada obowiązek, aby ostatni rozdział Dokumentacji Techniczno - Ruchowej (DTR) zawierał zasady recyklingu. Uregulowanie powyższe dotyczy nowych jak i modernizowanych pojazdów kolejowych, jego zespołów i podzespołów. Opis zasad recyklingu w opracowywanych DTR jest w większości przypadków na poziomie bardzo znacznego uogólnienia i tylko w nielicznych DTR znajdują się szczegółowe informacje dotyczące struktury składu materiałowego, przeprowadzania procesu utylizacji (w tym proces demontażu) i obliczania wskaźnika recyklingu i odzysku [13]. W Polsce tramwaj, mimo że jest pojazdem szynowym, podlega uregulowaniom ustawy $\mathrm{z}$ dnia 20 czerwca 1997 roku - Prawo o ruchu drogowym i przepisom wykonawczym do tej ustawy [27].

W 2011 roku minister infrastruktury wydał trzy istotne rozporządzenia dotyczące tramwajów [21-23].

1) Rozporządzenie Ministra Infrastruktury $z$ dnia 2 marca 2011 r. w sprawie warunków technicznych tramwajów i trolejbusów oraz zakresu ich niezbędnego wyposażenia, 
2) Rozporządzenie Ministra Infrastruktury $z$ dnia 2 marca 2011 r. w sprawie homologacji typu tramwajów i trolejbusów,

3) Rozporządzenie Ministra Infrastruktury $z$ dnia 28 stycznia 2011 r. w sprawie zakresu, warunków, terminów i sposobu przeprowadzania badań technicznych tramwajów i trolejbusów oraz jednostek wykonujących te badania.

\section{Skala problemu w Polsce}

W 1999 roku w Polsce było eksploatowanych 3781 tramwajów, a w 2011 roku liczba ta uległa zmniejszeniu do 3540 wagonów. Spadek liczby wagonów tramwajowych znalazł odzwierciedlenie w zmniejszeniu udziału tego środka transportu w przewozach pasażerskich ogółem z 1,8\% w 2005 roku do 1,4\% w 2008 roku. W krajach Unii Europejskiej w tym samym okresie udział przewozów pasażerskich tramwajami i metrem stanowił w każdym roku 1,5\%. W Polsce w tym samym czasie uległ zwiększeniu udział samochodów osobowych z 79,2\% w 2005 roku do $84,1 \%$ w 2008 roku, a w krajach UE udział ten ulegt zmniejszeniu z $82,2 \%$ do $81,9 \%$ na rzecz wzrostu udziału przewozów pociagami $[4,25,26]$.

Zmniejszenie liczby tramwajów wynikało $\mathrm{z}$ faktu, iż kasowano wagony zużyte technicznie o znacznie mniejszych możliwościach przewozowych pasażerów, a wprowadzano pojazdy o większej liczbie miejsc. Był to proces odwrotny w stosunku do eksploatowanych samochodów osobowych, których liczba od 2000 r. do 2009 r. uległa zwiększeniu z 495,8 mln do 529,0 mln sztuk, a samochodów ciężarowych z 197,5 mln do 214, 5 mln sztuk [19].

Wagony tramwajowe, podobnie jak inne pojazdy zbudowane są $\mathrm{z}$ różnych materiałów takich jak: stal, żeliwo, miedź, aluminium, szkło, guma, drewno, derma, laminaty, kompozyty, malarskie powłoki ochronne i smary. W tej sytuacji powtórne wykorzystanie wycofywanych z eksploatacji wagonów tramwajowych od wielu lat stało się i nadal jest aktualnym wyzwaniem, zarówno dla przewoźników podejmujących decyzje o ich wycofaniu, jak i producentów wagonów oraz administracji państwowej.

Problem recyklingu wagonów tramwajowych z jednej strony jest o wiele prostszy od recyklingu samochodów, ponieważ pojazdy te są wielokrotnie mniej rozproszone. W Polsce tramwaje eksploatowane są w 14 miastach i aglomeracjach miejskich. Latwiej jest zatem zorganizować miejsca składowania wagonów tramwajowych wycofanych z eksploatacji i przeznaczonych do złomowania. Sam proces recyklingu wagonu tramwajowego jest także prostszy organizacyjnie od recyklingu samochodu zwłaszcza z uwagi na udział złomu metali. Przeciętnie w wyniku recyklingu samochodu osobowego uzyskuje się około $700 \mathrm{~kg}$ złomu metali, a z recyklingu wagonu tramwajowego uzyskuje się przeciętnie od $5500 \mathrm{~kg}$ (bez zespołów, elementów i części nadających się do ponownego użycia) do $12800 \mathrm{~kg} \mathrm{w}$ przypadku przeznaczenia w całości wagonu na złom [32].

Z drugiej strony recykling wagonów tramwajowych jest o wiele trudniejszy od recyklingu samochodów, ponieważ bardzo długi okres życia tramwajów wynoszący nawet 55 lat utrudnia kompleksowe podejście do recyklingu, bo trudno dzisiaj przewidzieć, jakie będą technologie recyklingu za 40 czy 50 lat.

O liczbie eksploatowanych wagonów tramwajowych decydują wielkości przewozów pasażerów. W Polsce od 2000 roku odnotowuje się spadek przewozów pasażerów w komunikacji miejskiej. W 2000 roku przewieziono 4954 mln pasażerów, a w 2011 roku tylko $3890 \mathrm{mln}$ osób, co oznacza spadek o 21,5\%. Kształtowanie się przewozów pasażerskich w latach 20002011 przedstawiono $\mathrm{w}$ tabeli $1[25,26]$.

Wielkość przewozów pasażerskich w komunikacji miejskiej w latach 2000-2011 [25,26]

Tabela 1

\begin{tabular}{|c|c|c|}
\hline \multirow{2}{*}{ Rok } & \multicolumn{2}{|c|}{ Przewozy pasażerów [mIn] } \\
\cline { 2 - 3 } & w ciągu roku & w ciągu doby \\
\hline 2000 & 4954,1 & 13,6 \\
\hline 2005 & 3994,5 & 10,9 \\
\hline 2006 & 4001,3 & 11,0 \\
\hline 2007 & 4078,0 & 11,2 \\
\hline 2008 & 4066,1 & 11,1 \\
\hline 2009 & 3779,0 & 10,4 \\
\hline 2010 & 3904,9 & 10,7 \\
\hline 2011 & 3890,0 & 10,7 \\
\hline
\end{tabular}

Dane dotyczące liczby wagonów tramwajowych realizujących przewozy pasażerów w ostatnich latach przedstawiono w tabeli 2.

Na podstawie powyższych danych można stwierdzić, że liczba wagonów tramwajowych w 2011 roku w stosunku do 2002 roku uległa zmniejszeniu o 4,6\%. Pozytywnym zjawiskiem jest dynamiczny wzrost liczby wagonów tramwajowych przystosowanych do przewozu osób niepełnosprawnych. Wzrost ten w ciagu ostatnich ośmiu lat przekroczył $450 \%$. W całym okresie analizowanego dziesięciolecia dostępność i sprawność posiadanego taboru kształtowała się na poziomie od $73 \%$ do $76 \%$.

Proces recyklingu wagonów tramwajowych w Polsce, w praktyce występuje u dużych przewoźników mających na stanie kilkaset pojazdów. Wszystkich przewoźników tramwajowych, prowadzących działalność w latach 1999-2011 można podzielić pod względem ilości posiadanego taboru na [6, $10-12,32]$ : 
Stan ilościowy i wykorzystanie wagonów tramwajowych w Polsce w latach 2002-2011 [4, 25, 26

Tabela 2

\begin{tabular}{|c|c|c|c|}
\hline Rok & $\begin{array}{c}\text { Stan } \\
\text { inwenta- } \\
\text { rzowy }\end{array}$ & $\begin{array}{c}\text { Tramwaje przy- } \\
\text { stosowane do } \\
\text { przewozu osób }\end{array}$ & $\begin{array}{c}\text { Udzial } \\
\text { tramwajów } \\
\text { w ruchu do }\end{array}$ \\
\hline 2002 & 3710 & $\bullet$ & 74 \\
\hline 2003 & 3687 & $\bullet$ & 74 \\
\hline 2004 & 3642 & 107 & 75 \\
\hline 2005 & 3631 & 109 & 74 \\
\hline 2006 & 3619 & 117 & 74 \\
\hline 2007 & 3656 & 210 & 74 \\
\hline 2008 & 3672 & 205 & 73 \\
\hline 2009 & 3622 & 250 & 76 \\
\hline 2010 & 3620 & 390 & 76 \\
\hline 2011 & 3540 & 492 & 75 \\
\hline
\end{tabular}

- brak danych

1) Małych - posiadających do 100 pojazdów. $\mathrm{W}$ 2011 roku takich przewoźników było 5 (MPK Częstochowa, TE Elblagg, MZK Gorzów W1kp., MZK Grudziądz, MZK Toruń). Łącznie przewoźnicy ci mielina stanie 203 tramwaje.

2) Średnich - posiadających od 100 do 250 pojazdów. W 2011 roku takich przewoźników było 3 (MZK Bydgoszcz, ZKM Gdańsk, TSz. Szczecin), a łączny tabor wyniósł 498 tramwajów.

3) Dużych - posiadających powyżej 250 pojazdów. W 2011 roku takich przewoźników było 6 (TŚ Chorzów, MPK Kraków, MPK Łódź, MPK Poznań, TW Warszawa, MPK Wrocław). Posiadali łącznie 2821 tramwajów.

W 2011 roku w grupie małych przewoźników w 3 firmach kasacja w ogóle nie miała miejsca, a w 2 przedsiębiorstwach skasowano po jednym tramwaju [6].

O skali procesu recyklingu wagonów tramwajowych w Polsce decyduja podstawowe dwa czynniki:

1) program modernizacji wagonów tramwajowych,

2) program zakupów wagonów tramwajowych.

Każdy przewoźnik tramwajowy jest szczególnie zainteresowany odnawianiem posiadanego taboru. Proces ten realizowany jest $\mathrm{w}$ drodze zakupu nowych tramwajów oraz poprzez ekonomicznie uzasadnioną modernizację istniejących wagonów.

Proces odnawiania wagonów tramwajowych wymaga ciagłego analizowania wpływu wieku pojazdów, w całym okresie ich użytkowania, na koszty eksploatacji. Przy takim podejściu bezwzględnie należy określić granice ekonomicznej i technicznej eksploatacji wagonu w stosunku do wieku. Granica techniczna eksploatacji wagonu określa moment od kiedy wzrasta zawodność eksploatacji i jednocześnie obniża się bezpieczeństwo przewozów. Natomiast granicę ekono- miczną użytkowania tramwaju określa chwila od kiedy następuje znaczący wzrost kosztów eksploatacji.

Dodatkowym, szczególnie ważnym czynnikiem jest dostosowywanie posiadanego taboru do rosnących wymagań pasażerów. Dotyczy to zwłaszcza komfortu jazdy, dostępności dla osób starszych, niepełnosprawnych poruszających się na wózkach inwalidzkich oraz dla matek z dziećmi w wózkach.

Modernizacja posiadanego taboru i zakup używanych tramwajów z zagranicy była dla większości firm tramwajowych jedynym rozwiazaniem problemu starzejącego się taboru. Takie działanie wymuszała na krajowych przewoźnikach tramwajowych trudna sytuacja finansowa, uniemożliwiająca zakup nowego taboru.

W połowie pierwszej dekady XXI wieku w modernizacji tramwajów wyspecjalizowały się w Polsce dwie firmy: Protram Sp. z o.o. we Wrocławiu i Modertrans Sp. z o.o. w Poznaniu. Obie firmy wykonywały kompletne modernizacje, głównie wagonów 105N. Firma Modertrans podjęła się również modernizacji 46 tramwajów typu N8C dla Gdańska. Nie wszystkie podejmowane i zrealizowane w latach 2006 - 2012 modernizacje tramwajów były ekonomicznie uzasadnione. Wątpliwości budzi między innymi modernizacja w 2008 roku 40 sztuk tramwajów $105 \mathrm{~N}$ przez firmę Modertrans dla MPK Poznań. Zmodernizowanym tramwajom, które oznaczano symbolem Modertrans Alfa, nadano nowoczesną stylistykę zewnętrzną. Natomiast $\mathrm{w}$ ogóle nie zmodernizowano układu napędowego, pozostawiając klasyczny, przestarzały napęd prądu stałego.

W najbliższych latach, tj. w perspektywie do 2025 roku, zakłada się, że modernizacją objęte będą głównie tramwaje $105 \mathrm{Na}$ i $805 \mathrm{Na}$, które w pierwszym kwartale 2013 roku były eksploatowane w ilości 1728 sztuk. Szacuje się, że modernizacji poddane zostanie około 400 sztuk tych wagonów. Wagony te będą mogły być modernizowane $\mathrm{w}$ różnych konfiguracjach, między innymi jako tramwaje trójczłonowe $\mathrm{z}$ niskopodłogowym członem środkowym. Również zakładany jest wariant wykorzystania kompleksowo zmodernizowanego tramwaju $105 \mathrm{Na} \mathrm{z}$ nowoczesnym układem napędowym do ciagnięcia w składzie nowobudowanego wagonu doczepnego, całkowicie niskopodłogowego. Modernizacją objętą będzie część sprowadzanych z Niemiec i Austrii używanych tramwajów.

Każda modernizacja starego typu tramwaju, oprócz poprawy stylistyki pudła oraz podnoszenia komfortu jazdy dla pasażera, będzie obejmowała przede wszystkim zastosowanie nowoczesnego energooszczędnego układu napędowego prądu przemiennego.

Każde polskie miasto eksploatujące tramwaje prowadzi własną, odrębną politykę w zakresie modernizacji, rozwoju oraz zakupów nowego taboru. Na przełomie 2011 i 2012 roku, 9 spośród 14 miast posiadających sieć tramwajowa, dysponowało opracowanymi pla- 
nami lub programami modernizacji i rozwoju taboru tramwajowego do 2020 roku.

O wielkości zakupów do 2020 roku nowych wagonów tramwajowych będą decydowały następujące uwarunkowania:

- struktura wiekowa eksploatowanego taboru,

- ekonomicznie uzasadniony proces modernizacji istniejącego taboru,

- proces odtwarzania (zakupu nowych tramwajów).

O strukturze wiekowej eksploatowanych tramwajów decyduje wielkość dokonywanych dostaw nowego taboru. Począwszy od lat dziewięćdziesiątych XX wieku przewoźnicy tramwajowi w większości polskich miast częściowo unowocześniali posiadany tabor poprzez dostawy (zakupy, darowizny) używanych pojazdów, głównie z Niemiec, Holandii i Austrii. Zakupy te pozwoliły wyeliminować najbardziej zużyte wagony tramwajowe. Kształtowanie się dostaw tramwajów w Polsce w latach 1999 - 2011 przedstawiono w tabeli 3 .

Dostawy taboru tramwajowego w Polsce w latach 1999-2011 [6]

Tabela 3

\begin{tabular}{|c|c|c|}
\hline \multirow{2}{*}{ Rok } & \multicolumn{2}{|c|}{$\begin{array}{c}\text { Dostawy tramwajów } \\
\text { w szt. }\end{array}$} \\
\cline { 2 - 3 } & Ogółem & w tym nowe \\
\hline 1999 & 42 & 26 \\
\hline 2000 & 58 & 38 \\
\hline 2001 & 110 & 93 \\
\hline 2002 & 29 & 15 \\
\hline 2003 & 38 & 12 \\
\hline 2004 & 35 & 5 \\
\hline 2005 & 6 & 0 \\
\hline 2006 & 56 & 15 \\
\hline 2007 & 92 & 67 \\
\hline 2008 & 116 & 33 \\
\hline 2009 & 49 & 2 \\
\hline 2010 & 153 & 45 \\
\hline 2011 & 239 & 158 \\
\hline
\end{tabular}

Z danych zawartych w tabeli 3 wynika, że w całym analizowanym okresie w dostawach tramwajów ogółem, nowy tabor stanowił 46,5\%. Szczególny wzrost wielkości dostaw taboru tramwajowego, zarówno ogółem jak i nowego, nastapił w latach 2010-2011. Związane to było z przygotowaniami Polski do Mistrzostw Europy w Piłce Nożnej EURO 2012 i zakupami, zwłaszcza nowego taboru, przez miasta będące gospodarzem rozgrywek i miasta rezerwowe turnieju.

\section{Program recyklingu wagonów tramwajowych w Polsce}

Program recyklingu wagonów tramwajowych w Polsce uwarunkowany jest dwoma czynnikami:
- wiekiem eksploatowanych tramwajów, a więc ich technicznym zużyciem,

- możliwościami finansowymi poszczególnych miast, pozwalającymi na odnawianie posiadanego taboru przez podległe firmy przewozowe.

Ponadto nie ma ogólnokrajowego programu recyklingu wagonów tramwajowych. Każde miasto eksploatujące tramwaje opracowuje własne programy. W oparciu o dokonane analizy posiadanego taboru, uwzględniające liczbę według typów, wiek wagonów, ich rozwiązania konstrukcyjne, techniczne, zużycie oraz tendencje rozwojowe przygotowywane są plany wycofywania $\mathrm{z}$ eksploatacji wagonów tramwajowych. W planach tych uwzględnione są zakupy nowych wagonów, pojazdy przeznaczone do przebudowy w ramach kompleksowej modernizacji, a także sprzedaż lub przekazanie pewnej liczby tramwajów innym podmiotom.

Sprzedaż lub przekazanie dotyczy jednostkowych egzemplarzy, w szczególności:

- przekazanie danego typu tramwaju do jednostek muzealnych,

- sprzedaż osobom fizycznym w celach kolekcjonerskich,

- pozostawienie jednego lub kilku wagonów danego typu w firmach eksploatujących tramwaje jako egzemplarze ,retro” (tabor historyczny),

- przekazywanie pojedynczych egzemplarzy na licytacje w celach charytatywnych.

Od lat dziewięćdziesiątych XX wieku do chwili obecnej, w przypadku braku możliwości (głównie z przyczyn finansowych) zakupu nowego taboru, miasta decydują się na czasowe, przejściowe odnowienie posiadanego parku, poprzez zakup z zagranicy pojazdów używanych.

$\mathrm{Na}$ podstawie analizy uzyskanych materiałów oraz informacji dotyczących eksploatowanego taboru tramwajowego określono program recyklingu wagonów tramwajowych w Polsce na najbliższe 20 lat.

Recykling wagonów tramwajowych, wynikający $\mathrm{z}$ kasacji zużytych technicznie wagonów do 2035 roku, można podzielić na dwie różniące się od siebie fazy [32]:

- faza pierwsza - w okresie od 2014 roku do 2025 roku,

- faza druga - w okresie od 2025 roku do 2035 roku.

\section{Faza pierwsza}

Będzie dotyczyła prawie wyłącznie wagonów typu $105 \mathrm{Na}$ i $805 \mathrm{Na}$ produkcji chorzowskiego Konstalu. Według stanu na koniec lutego 2013 roku, w Polsce było eksploatowanych łącznie 1728 sztuk wagonów typu $105 \mathrm{Na}$ i $805 \mathrm{Na}$, co stanowiło niecałe $50 \%$ ogółu jeżdżących tramwajów w kraju. W tej ogólnej liczbie 
1728 sztuk było 627 wagonów tramwajowych typu $805 \mathrm{Na}$. Tramwaje typu $105 \mathrm{Na}$ i $805 \mathrm{Na}$ w lutym 2013 roku były eksploatowane we wszystkich 14 zarządach tramwajowych w Polsce. Najstarsze z tych tramwajów mają blisko 40 lat, a najmłodsze zostały wyprodukowane w 1992 roku.

Stan wagonów tramwajowych typu $105 \mathrm{Na}$ i $805 \mathrm{Na}$ w lutym 2013 roku w poszczególnych firmach przewozowych przedstawiono w tabeli 4 .

Stan tramwajów typu 105Na i 805Na na dzień 27.02.2013 r. [8, 10-12, 24, 32, 34-54] Tabela 4

\begin{tabular}{|c|l|c|c|c|}
\hline Lp. & \multicolumn{1}{|c|}{ Przewoźnik } & $\begin{array}{c}\text { Typ } \\
\text { wagonu }\end{array}$ & Lata dostaw & $\begin{array}{c}\text { Stan } \\
\text { liczeb } \\
\text { ny } \\
\text { w szt. }\end{array}$ \\
\hline $\mathbf{1}$ & MZK Bydgoszcz & $805 \mathrm{Na}$ & $1977-1990$ & 112 \\
\hline $\mathbf{2}$ & MPK Częstochowa & $105 \mathrm{Na}$ & $1975-1990$ & 48 \\
\hline $\mathbf{3}$ & TE Elbląg & $805 \mathrm{Na}$ & $1980-1990$ & 21 \\
\hline $\mathbf{4}$ & ZKM Gdańsk & $105 \mathrm{Na}$ & $1975-1990$ & 60 \\
\hline $\mathbf{5}$ & MZK Gorzów & $105 \mathrm{Na}$ & $1975-1988$ & 17 \\
\hline $\mathbf{6}$ & TŚ Chorzów & $105 \mathrm{Na}$ & $1974-1989$ & 218 \\
\hline $\mathbf{7}$ & MZK Grudziądz & $805 \mathrm{Na}$ & $1980-1988$ & 13 \\
\hline $\mathbf{8}$ & MPK Kraków & $105 \mathrm{Na}$ & $1975-1992$ & 149 \\
\hline $\mathbf{9}$ & MPK Lódź & $805 \mathrm{Na}$ & $1977-1990$ & 426 \\
\hline $\mathbf{1 0}$ & MPK Poznań & $105 \mathrm{Na}$ & $1975-1990$ & 136 \\
\hline $\mathbf{1 1}$ & TSz Szczecin & $105 \mathrm{Na}$ & $1975-1992$ & 56 \\
\hline $\mathbf{1 2}$ & MZK Toruń & $805 \mathrm{Na}$ & $1980-1990$ & 55 \\
\hline $\mathbf{1 3}$ & TW Warszawa & $105 \mathrm{Na}$ & $1973-1992$ & 297 \\
\hline $\mathbf{1 4}$ & MPK Wroclaw & $105 \mathrm{Na}$ & $1975-1991$ & 120 \\
\hline
\end{tabular}

Po uwzględnieniu zużycia technicznego tych pojazdów, dokonanych napraw głównych i przeprowadzonych modernizacji, szacuje się, że przeciętnie rocznie w latach 2014 - 2025 będzie wycofywanych z eksploatacji, z przeznaczeniem do modernizacji lub całkowitego złomowania od 120 do 150 wagonów tramwajowych typu $105 \mathrm{Na}$ i $805 \mathrm{Na}$.

Niektóre zarządy firm tramwajowych, w tym między innymi TW Warszawa, MPK Wrocław, MPK Łódź i MPK Poznań, część eksploatowanych wagonów zamierzają przeznaczyć do kompleksowej modernizacji. Szacuje się, że tym procesem objętych zostanie około $20 \%$ obecnego taboru tych tramwajów.

\section{Faza druga}

W tej fazie procesem recyklingu będą objęte przede wszystkim sprowadzone do kraju w ostatnich latach używane wagony tramwajowe z Europy Zachodniej. Głównie będzie to dotyczyło trzech firm tramwajowych - MPK Kraków i TSz Szczecin i TŚ Chorzów. Firmy te sprowadzały do Polski wagony E1 produkcji firmy Lohner i Simmering - Graz - Pauker oraz KT4Dt i T6A2D produkcji czeskiej Tatry. Wcześniej sprowadzono do Polski używane tramwaje firmy Düwag w tym wagony typu GT8.

W latach 2006 - 2011 dostawy do 9 polskich przewoźników tramwajowych wyniosły łącznie 385 sztuk wagonów używanych $[4,6,14,32]$.

Grupa zakupionych i otrzymanych, używanych wagonów stanowi około $15 \%$ ogółu tramwajów. Niektóre wagony $\mathrm{z}$ tej grupy pojazdów będą wycofywane $\mathrm{z}$ eksploatacji przed 2025 rokiem.

Pod koniec drugiej fazy, liczbę wagonów przeznaczonych do recyklingu powiększą nowoczesne tramwaje zakupione na początku XXI wieku. Jak wynika z dokonanych analiz, żywotność tych tramwajów nie bedzie przekraczała 35 lat.

Jednym z czynników, który może przyspieszyć wycofywanie $\mathrm{z}$ eksploatacji starych wagonów jest fakt, że aż około $85 \%$ obecnie eksploatowanego taboru tramwajowego w Polsce posiada klasyczne, przestarzałe i nieekonomiczne układy napędowe.

W świetle występujących obecnie tendencji szukania energooszczędnych rozwiązań w zakresie napędów tramwajowych proces recyklingu wagonów może wystąpić w większej skali od prognozowej.

Ponadto recykling występuje nie tylko przy całkowitej likwidacji wagonów tramwajowych, ale także w procesie napraw okresowych i napraw bieżących. Dotyczy to napraw pudeł wagonów w wyniku uszkodzeń mechanicznych, a także realizacji napraw i wymiany zestawów kołowych wynikających $\mathrm{z}$ dokumentacji utrzymana tramwajów.

\section{Uwarunkowania przeprowadzania recyklingu wagonów tramwajowych}

Skuteczność procesu recyklingu wagonów tramwajowych uzależniona jest od szeregu uwarunkowań, okoliczności i czynników. Najważniejsze z nich można pogrupować następująco:

1) Uwarunkowania prawne,

2) Uwarunkowania ekonomiczne,

3) Uwarunkowania konstrukcyjnotechnologiczne,

4) Uwarunkowania bezpieczeństwa ekologicznego,

5) Uwarunkowania społeczne.

\section{Uwarunkowania prawne}

Regulacje prawne powinny w jasny i przejrzysty sposób określać obowiązki i wymagania wobec wszystkich podmiotów uczestniczących w życiu technicznym wagonów tramwajowych, a więc:

- projektantów, konstruktorów i technologów,

- producentów taboru,

- użytkowników,

- firm dokonujących recyklingu. 
Do chwili obecnej żadne przepisy, ani Unii Europejskiej, ani też krajowe, nie zobowiązują producentów wagonów tramwajowych, w sposób obligatoryjny do odbioru, zapewnienia odzysku i recyklingu ich produktów oraz uzyskania odpowiednich wskaźników odzysku. Odbywa się to na zasadzie dobrowolności i zaczyna być stosowane przez niektóre znaczące firmy europejskie. Producenci wagonów tramwajowych nie ponoszą opłat produktowych za nie osiagnięcie wymaganego poziomu recyklingu. Producenci wagonów tramwajowych nie muszą egzekwować od konstruktorów zapewnienia, już na etapie projektowania, określonego poziomu recyklingu, $w$ tym stosowania materiałów nadających się do ponownego odzysku i rozwiązań ułatwiających demontaż.

\section{Uwarunkowania ekonomiczne}

Najważniejszymi elementami tych uwarunkowań są koszt i czas. Na całkowity koszt wpływa wiele elementów składowych takich jak:

- koszt przygotowania wagonu tramwajowego do kasacji,

- koszt czasowego (przejściowego) magazynowania wagonu przeznaczonego do złomowania,

- koszt transportu wagonu tramwajowego na miejsce złomowania,

- koszt demontażu i selektywnego odzysku materiałów (z uwzględnieniem pełnej segregacji),

- koszt transportu posegregowanych materiałów i surowców do finalnego odbiorcy (huty i odlewnie metali i szkła, firmy przetwarzające tworzywa sztuczne, firmy przerabiajacce gumę),

- koszty utylizacji odpadów nienadających się do ponownego przerobu.

Czas jest tym elementem, który w znacznym stopniu decyduje o całkowitym koszcie procesu recyklingu wagonów tramwajowych. Im szybciej i sprawniej zostanie przeprowadzony całkowity proces recyklingu taboru, tym mniejsze będą między innymi koszty magazynowania w poszczególnych fazach.

Ponadto istotnym elementem uwarunkowań ekonomicznych jest stworzenie systemu zachęt oraz opłat sankcyjnych.

Coraz częściej w warunkach zakupu nowych tramwajów, firmy eksploatujące pojazdy, wymagają zapewnienia przez producenta pogwarancyjnej obsługi serwisowej, łącznie $\mathrm{z}$ wykonaniem naprawy głównej przez okres kilkunastu lat, a nawet powyżej 20 lat. Działania te zmierzają w tym kierunku, aby zobowiązać wytwórców tramwajów do odbioru własnych produktów po zakończeniu ich eksploatacji.

\section{Uwarunkowania konstrukcyjno-technologiczne}

Dotyczą zwłaszcza zastosowania w projektowaniu wagonu tramwajowego takich materiałów i takich technologii, które zapewnią zarówno łatwy i prosty montaż, jak i później demontaż wagonu tramwajowego. Szczególnie dotyczy to unikania stosowania wielowarstwowych i kompozytowych materiałów, jak i trudnych technologii np. specyficznego klejenia czy uszczelnienia, powodujących trudności w recyklingu.

Konstruktorzy powinni ponadto zapewnić określony opis procedur technicznych zapewniających jak najwyższy poziom odzysku materiałów i surowców umożliwiających ich ponowne przetworzenie.

\section{Uwarunkowania bezpieczeństwa ekologicznego}

$\mathrm{W}$ procesie złomowania wagonu tramwajowego gospodarka odpadami powinna być tak zorganizowana, aby nie powodowała zagrożenia dewastacji środowiska naturalnego.

Odstawianie i składowanie, nieraz latami, wagonów tramwajowych przeznaczonych do kasacji powoduje niszczenie krajobrazu środowiskowego. Stojące przez dhugi okres wagony tramwajowe przeznaczone do złomowania powodują niejednokrotnie skażenie ziemi np. przez wycieki smarów i elektrolitu z akumulatorów, a także odpadające, skorodowane powłoki malarskie i uszczelnienia.

Przy rozrywaniu i rozbijaniu na mniejsze elementy pudeł wagonów tramwajowych, emitowany jest hałas znacznie przekraczajacy dopuszczalne normy. Ponadto przy ręcznym rozcinaniu palnikami całych wagonów tramwajowych istnieje zagrożenie wywołania pożaru.

\section{Uwarunkowania społeczne}

Ramowa Dyrektywa Unii Europejskiej o odpadach [3] określa, że jednym z głównych celów jest stworzenie „społeczeństwa recyklingu”. Można to osiagnąć poprzez:

- promowanie wysokiej jakości recyklingu,

- zmianę podejścia do odzysku i recyklingu,

- zapewnienie szerokiej informacji i edukacji w zakresie odzysku i recyklingu kształtującej świadomość społeczeństwa,

- kształcenie specjalistów w zakresie recyklingu pojazdów szynowych.

Recykling pojazdów szynowych, w tym wagonów tramwajowych, w najbliższych latach musi stać się dynamicznie rozwijająca branżą usług. Ale o tym w głównej mierze zadecyduje jakość i profesjonalizm systemu demontażu wagonów.

\section{Zagospodarowanie wycofanych wagonów tramwajowych przez Tramwaje Warszawskie}

Wobec braku zarówno międzynarodowych jak i krajowych uregulowań prawnych w zakresie recyklingu wagonów tramwajowych, największy polski przewoźnik Tramwaje Warszawskie Sp. z o.o. dokonuje kasacji wagonów w oparciu o własne, wewnętrzne uregulowania, stworzone na bazie wieloletnich doświad- 
czeń, a także w oparciu o przepisy prawne z zakresu ochrony środowiska i uregulowania dla innych branż, w tym branży samochodowej.

Tramwaje Warszawskie w 2009 roku wdrożyły Zintegrowany System Zarządzania, a jednym z jego elementów jest System Zarządzania Środowiskowego, którego głównym celem jest ciąłe minimalizowanie negatywnego oddziaływania na środowisko. Podejmowane w tym zakresie działania ukierunkowane są między innymi na zrównoważone wykorzystanie materiałów i surowców, zwiększenie bezpieczeństwa ekologicznego $\mathrm{w}$ gospodarce tramwajami, utrzymania taboru oraz całej infrastruktury $[11,18]$. Spółka Tramwaje Warszawskie posiada wymagane pozwolenie na wytwarzanie odpadów i gospodarowanie nimi oraz zbiórkę i składowanie surowców wtórnych, powstających w wyniku kasacji wagonów ich przeglądów i napraw oraz wymiany w nich podzespołów [11, 17].

Tramwaje Warszawskie w 2009 roku ogłosiły deklarację środowiskową, stanowiąca zobowiązanie do zachowania zasad poszanowania i ochrony środowiska naturalnego.

Wlaściciel wagonu tramwajowego Tramwaje Warszawskie Sp. z o.o.

Jednostka eksploatująca tramwaj typuje wagon przeznaczony do likwidacji

Wniosek o dokonanie kasacji wagonu tramwajowego

Komisyjna ocena stanu technicznego wagonu

Decyzja Zarządu Spółki TW o wycofaniu wagonu z eksploatacji i przeznaczaniu do kasacji

Decyzja o likwidacji wagonu jako środka trwałego

Uruchomienie zlecenia fizycznej likwidacji wagonu

Komisyjne potwierdzenie kompletności wyposażenia i elementów wagonu /stwierdzenie braków wyposażenia/

Ostateczne ustalenie listy podzespołów i części nadających się do ponownego wykorzystania

\begin{tabular}{|c|c|c|}
\hline \multicolumn{3}{|c|}{ Przeprowadzenie recyklingu wagonu } \\
\hline Recykling produktowy & Recykling materialowy & Recykling energetyczny \\
\hline 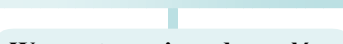 & 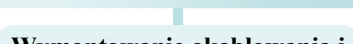 & 1 \\
\hline $\begin{array}{l}\text { Wymontowanie podzespołów, } \\
\text { elementów i części nadających } \\
\text { się do dalszej eksploatacji }\end{array}$ & $\begin{array}{c}\text { Wymontowanie okablowania i } \\
\text { innych elementów z metali } \\
\text { nieżelaznych }\end{array}$ & $\begin{array}{l}\text { Wymontowanie elementów } \\
\text { gumowych, drewnianych, } \\
\text { szklanych, obiciowych i smarów }\end{array}$ \\
\hline & Pocięcie na zlom części & \\
\hline $\begin{array}{l}\text { Przyjęcie części elementów } \\
\text { i podzespolów do magazynu }\end{array}$ & $\begin{array}{c}\text { stalowych } \\
\text { Sprzedaż zlomu metalowego }\end{array}$ & $\begin{array}{c}\text { Sprzedaż drewna i pozostałych } \\
\text { elementów }\end{array}$ \\
\hline
\end{tabular}

Rys. 1. Procedura postępowania w Tramwajach Warszawskich Sp. z o.o. z wagonami przeznaczonymi do recyklingu (opracowanie własne na podstawie [29-31]) 
amortyzacją pojazdów, uregulowane są postanowieniami Zarządzenia nr 6/96 z dnia 24 kwietnia 1996 r. Dyrektora Zakładu Budżetowego „Tramwaje Warszawskie" w Warszawie, w sprawie zasad gospodarowania, ewidencji i obiegu dokumentów dotyczących środków trwałych i pozostałych środków trwałych w użytkowaniu [31]. Te dwa dokumenty pozwalają określić procedurę postępowania w Tramwajach Warszawskich $\mathrm{z}$ wagonami tramwajowymi przeznaczonymi do recyklingu, który przedstawiono na rysunku 1.

We wszystkich przedsiębiorstwach realizujących przewozy tramwajowe w Polsce, przez większość lat w okresie 1999-2012 recykling kasowanego taboru odbywał się ręcznie i stanowił dominującą metodę pozyskiwania w pierwszej kolejności zespołów, elementów i części nadających się do dalszego użytku lub regeneracji.

Proces recyklingu tramwajów w Spółce Tramwaje Warszawskie rozpoczynał się od podniesienia wagonu i wykonania następujących prac:

- wymontowania wózków i ich demontaż,

- wymontowania skrzyni aparaturowej i jej demontaż na podzespoły, elementy i części,

- wymontowania skrzyni rozrusznika i jej demontaż,

- demontażu skrzyni baterii akumulatorów,

- wymontowania czuwaka, nawrotnika i nastawnika,

- wymontowania przetwornicy wirującej.

Po opuszczeniu wagonu następował całkowity demontaż wnętrza pudła i nadwozia. Zakres tych prac obejmowat:

- demontaż urządzeń elektrycznych,

- zerwanie chodnika z dachu,

- demontaż płyt sufitowych z oblistwowaniem,

- demontaż boazerii i wyłożeń z oblistwowaniem,

- zerwanie wykładziny gumowej,

- demontaż podłogi i belek podpodłogowych,

- demontaż kabiny motorniczego,

- demontaż instalacji elektrycznej,

- rozszklenie okien i drzwi (usunięcie szyb),

- demontaż sprzęgów,

- wymontowanie przetwornicy.

Recykling wagonów przeprowadzany był z należyta starannością, w szczególności w zakresie odzyskiwania zespołów, podzespołów, elementów i części, segregacji złomu metalowego, drewna, odpadów oraz minimalizacji ubytków. Podczas realizacji procesu recyklingu w Tramwajach Warszawskich zachowywana była szczególna staranność w zakresie przestrzegania obowiązujących przepisów BHP, przeciwpożarowych i ochrony środowiska. Szczególny nacisk kładziono na to, aby żaden zespół, podzespół, element czy część zakwalifikowany na złom nie mógł być ponownie wykorzystywany w innym wagonie.

W procesie recyklingu szczególną uwagę przykładano do demontażu kompletnego wózka. Po umyciu wózka przeprowadzano wzrokową ocenę jego elementów pod względem braku pęknięć, pokrzywień, przerdzewiałych miejsc ramy i w przypadku zakwalifikowania do ponownego wykorzystania cały wózek trafiał do regeneracji. Jednak w wyniku kasowania znacznej liczby wagonów $105 \mathrm{Na}$ i wszystkich wagonów $13 \mathrm{~N}$ (do końca 2012 r.) obecnie występuje coraz mniejsze zapotrzebowanie na regenerację całego wózka.

Recykling w pełnym zakresie wózków tramwajów kasowanych w ostatnich latach w największych ilościach (wagony typu $13 \mathrm{~N}$ i $105 \mathrm{Na}$ ) obejmował następujący zakres:

- wymontowanie zestawów kołowych,

- demontaż kół i łożysk wraz z obejmami,

- demontaż przekładni dwustopniowej (wagon $13 \mathrm{~N}$ ) lub jednostopniowej (wagon $105 \mathrm{Na}$ ),

- wymontowanie belki bujakowej z otworami czopa skrętu,

- wymontowanie luzownika hamulca bębnowego,

- wymontowanie sprężyny gumowo-metalowej łączącej ramę wózka z belką bujakową,

- wymontowanie elektromagnetycznego hamulca szynowego,

- wymontowanie silników trakcyjnych.

Po wyselekcjonowaniu zespołów, podzespołów, elementów i części nadających się do dalszego użytkowania przystępowano do przewiezienia części o niewielkich gabarytach na wyznaczone miejsca składowania złomu według poszczególnych klas złomu, zgodnie $\mathrm{z}$ polską normą $\mathrm{PN}-85 / \mathrm{H}-15000$ oraz pocięcia ręcznie przy pomocy palników pudła wagonu.

\section{Miejsca przeprowadzania recyklingu wagonów tramwajowych w Polsce}

Miejsca przeprowadzania recyklingu wagonów tramwajowych w Polsce jeszcze kilka lat temu były ściśle związane $\mathrm{z}$ przedsiębiorstwami posiadającymi tabor tramwajowy. To na terenie tych firm w praktyce dokonywano recyklingu posiadanego taboru. Było to możliwe, kiedy liczba kasowanych rocznie wagonów była niewielka, a przewoźnicy tramwajowi byli zainteresowani pozyskaniem jak największej liczby zespołów, elementów i części nadających się do napraw i bieżącej obsługi pozostałych w eksploatacji tramwajów danego typu.

W wyniku narastającego procesu starzenia się taboru oraz znaczącej jego odnowy w latach 2010-2012, zwłaszcza u dużych przewoźników w miastach, gdzie odbywały się mecze EURO 2012, podjęto decyzje o kasacji kilkuset sztuk technicznie zużytego taboru danego typu, a nawet likwidacji wszystkich wagonów 
określonego typu. Zjawisko to przede wszystkim miało miejsce w Tramwajach Warszawskich Sp. z o. o., gdzie sukcesywne włączanie nowych tramwajów typu $120 \mathrm{Na}$ dostarczonych z kontraktu na dostawę 186 pojazdów umożliwiło zarządowi firmy podjęcie decyzji o całkowitej kasacji do końca 2012 roku kilkuset wagonów typu $13 \mathrm{~N}$ oraz znacznej liczby pojazdów typu $105 \mathrm{~N}$. Spółka ta nie była już zainteresowana pozyskiwaniem dużej liczby zespołów, elementów i części do celów utrzymania taboru w wyniku przeprowadzania recyklingu we własnym zapleczu naprawczo-usługowym. Ponadto Spółka Tramwaje Warszawskie nie posiadała własnych mocy przerobowych do realizacji fizycznej likwidacji tak znaczącej liczby tramwajów w krótkim okresie. Firma przeprowadzała ręczny recykling wagonów, co stało się ekonomicznie nieuzasadnione.

W tej sytuacji Tramwaje Warszawskie, zdecydowały się w 2010 roku na recykling wagonów, poprzez sprzedaż całych wagonów w drodze licytacji bądź nieograniczonego przetargu, za ściśle określoną cenę. W ślad ze Tramwajami Warszawskimi poszli inni przewoźnicy w kraju.

Od tego czasu recykling wagonów tramwajowych w coraz większym zakresie przeprowadzały wyspecjalizowane firmy zajmujące się przerobem złomu na skalę przemysłową.

Główne miejsca recyklingu wagonów tramwajowych w Polsce, w latach 1999-2012, zarówno metodą ręczna, jak i zmechanizowana, przedstawiono na rysunku 2.

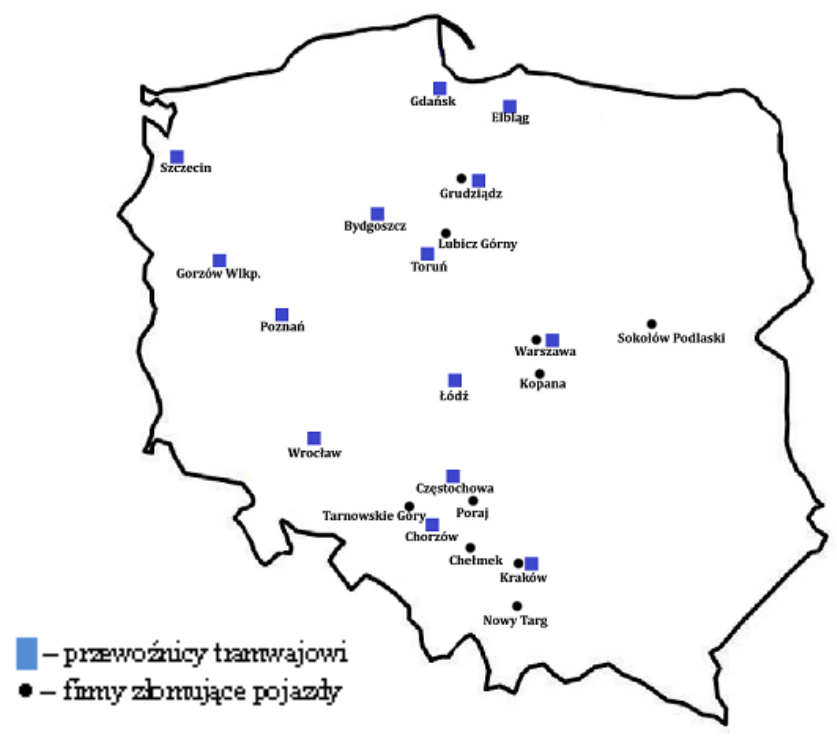

Rys. 2. Główne miejsca realizacji recyklingu wagonów tramwajowych w Polsce

\section{Zakres recyklingu}

W recyklingu wagonów tramwajowych stosowane są dwie metody: ręczna i mechaniczna. Metoda ręczna jest stosowana zawsze wtedy, kiedy głównym celem jest odzysk elementów, zespołów i podzespołów do dalszego użytkowania.
Właściwie dokonany demontaż wagonów tramwajowych wycofywanych z eksploatacji stanowi pierwszy krok w jego recyklingu. Dokładność oraz jakość demontażu wyznaczają możliwości ponownego użycia lub przetworzenia części składowych i podzespołów.

W wyniku recyklingu wagonów tramwajowych można pozyskać:

- zespoły, podzespoły, elementy i części wykorzystywane $\mathrm{w}$ naprawach okresowych modernizacyjnych, a nawet $\mathrm{w}$ produkcji nowych wagonów tramwajowych,

- złom metali, głównie stalowy oraz niewielkie ilości złomu żeliwnego, a także metali nieżelaznych, jak miedź, aluminium, mosiądz, brąz i srebro,

- inne materiały, wykorzystywane również jako surowiec energetyczny.

W wyniku kasacji wagonów tramwajowych mamy zatem do czynienia z:

- recyklingiem produktowym,

- recyklingiem materiałowym,

- odzyskiem energii.

W procesie kasacji i złomowania wagonów tramwajowych po dokonaniu wymontowania i demontażu zespołów, podzespołów, elementów i części oraz przeprowadzania ich oceny, umożliwiającej dalsze ich wykorzystywanie w eksploatacji można uzyskać następujące produkty:

- wózki,

- ramy wózków,

- zestawy kołowe,

- osie,

- przekładnie,

- silniki trakcyjne,

- elektromagnetyczne hamulce szynowe,

- przetwornice wirujące,

- skrzynie rozrusznika,

- rozrusznik komutatorowy,

- oporniki,

- skrzynie aparaturowe,

- elementy wyposażenia skrzyni aparaturowej,

- pantograf (odbierak prądu),

- sprzęgi,

- szkielet pudła.

Pozyskanie powyższych zespołów, elementów, części do napraw, modernizacji i produkcji nowych wagonów tramwajowych ma istotny wpływ na opłacalność procesu recyklingu.

Odzyskane produkty z kasowanych wagonów tramwajowych $w$ fazie złomowania, dokonywanego przez przewoźników tramwajowych we własnym zakresie, stanowią w zależności od typu pojazdu od około $20 \%$ do $60 \%$ masy $[9,11,12]$. 
W wyniku recyklingu wagonów tramwajowych największą odzyskiwaną masę stanowi złom stalowy zaliczany zgodnie z polską normą $\mathrm{PN}-85 / \mathrm{H}-15000$ do następujących klas:

1) W1 - złom stalowy kawałkowy wsadowy niestopowy o największych wymiarach $1000 \mathrm{x}$ $500 \times 500 \mathrm{~mm}$ o grubości $6 \mathrm{~mm}$ i powyżej oraz maksymalnej masie $2000 \mathrm{~kg}$, koła i obręcze kolejowe o średnicy do $1100 \mathrm{~mm}$,

2) N10 - złom stalowy pomieszany niewsadowy, niestopowy.

Niezależnie od powyższych dominujących klas złomu, w wyniku recyklingu wagonów tramwajowych, uzyskuje się niewielkie ilości wysokiej klasy łożyskowego złomu stopowego oraz złomu żeliwnego. Udział uzyskiwanego łożyskowego złomu stopowego zależnie od typu tramwaju stanowi od $0,2 \%$ i nie przekracza $0,5 \%$ całkowitej masy wagonu, a udział złomu żeliwnego stanowi do $0,6 \%$ ogólnej masy wagonu.

Ponadto w wyniku złomowania całego tramwaju, jak i niektórych zespołów i elementów jego wyposażenia, uzyskuje się kilkaset kilogramów złomu metali kolorowych takich jak: miedź, aluminium i mosiądz. Z samego okablowania wagonu tramwajowego można przeciętnie pozyskać około $170 \mathrm{~kg}$ złomu miedzi. Dodatkowe ilości miedzi uzyskuje się w przypadku złomowania silników trakcyjnych i rozrusznika oraz silników pomocniczych jak np. wycieraczki czy silnika pilotującego rozrusznik. Należy również wspomnieć, że ze złomowania tramwaju pozyskuje się około kilkuset gram srebra.

Poza złomem metalowym w wyniku recyklingu wagonów tramwajowych otrzymuje się wysokiej jakości stłuczkę szklaną. Jest ona między innymi przetwarzana na płytki ceramiczne o wysokiej wytrzymałości.

$\mathrm{W}$ procesie recyklingu wagonów tramwajowych odzyskuje się materiały, które mogą być wykorzystywane są jako surowiec energetyczny.

Do tych materiałów należą przede wszystkim drewno, elementy gumowe, niewielkie ilości smarów oraz derma i brezenty, a także różnego rodzaju pianki stanowiące wypełnienia siedzeń. Uzysk drewna ze złomowania wagonów typu $105 \mathrm{Na}$ i $13 \mathrm{~N}$ wynosi od 510 $\mathrm{kg}$ do $830 \mathrm{~kg}$ i stanowi to od $2,9 \%$ do $4,7 \%$ przeciętnej masy kasowanych tramwajów.

$\mathrm{Na}$ otrzymane $\mathrm{w}$ procesie złomowania wagonów tramwajowych elementy gumowe składają się uszczelki drzwi i okien, podłoga oraz odzysk z elementów gumowo-metalowych. Pochodzące $z$ recyklingu elementy gumowe mogą być wykorzystywane jak surowiec energetyczny np. w cementowniach. Mogą być również wykorzystywane, po zmieleniu, jako surowiec do budowy nawierzchni dróg i autostrad. Niezależnie od powyższego wykorzystania, pod koniec lat dziewięćdziesiątych XX wieku w Japonii opracowano technologię dewulkanizacji zużytych elementów gumowych (jak np. uszczelki) pozwalających na ponowne wytwarzanie $\mathrm{z}$ użyciem nowych surowców tych samych produktów (np. uszczelki) [7]. $\mathrm{W}$ wyniku recyklingu kasowanych tramwajów, oprócz odzysku produktów i materiałów nadających się do ponownego użycia, powstają odpady, które podlegają wyłącznie składowaniu. Na odpady te składają się głównie skorodowane powłoki malarskie, pozostałości uszczelnień, zabrudzenia i zanieczyszczenia pochodzące z kilkunastoletniej, a nierzadko z kilkudziesięcioletniej eksploatacji. Odpady te, zależnie od typu wagonu stanowią od $1,3 \%$ do $3,8 \%$ przeciętnej masy wagonu tramwajowego.

\section{Podsumowanie}

Mimo że nie istnieją w obszarze pojazdów szynowych regulacje prawne odnoszące się do recyklingu wycofanego z eksploatacji taboru, odpowiednie zagospodarowanie tego typu odpadów jest koniecznością wynikająca z ogólnych zasad gospodarowania odpadami. Do tej pory główną motywacją do przeprowadzania recyklingu były korzyści ekonomiczne jakie można czerpać z odzysku metali lub sprzedaży podzespołów nadających się do dalszego wykorzystania. Należy liczyć się jednak z tym, że zwłaszcza w krajach rozwiniętych, gdzie wdrażana jest polityka zrównoważonego rozwoju, problematyka recyklingu pojazdów szynowych stanie się przedmiotem zainteresowania, a docelowo ścisłych regulacji prawnych.

Recykling winien być traktowany jako priorytetowe zagadnienie w okresie całego życia technicznego wagonu tramwajowego od założeń koncepcyjnych aż do fizycznej likwidacji.

$\mathrm{Na}$ etapie projektowania powinny być wprowadzone materiały zdatne do recyklingu, a także technologie zapewniające łatwy demontaż tramwaju. Trzeba wprowadzić system nowoczesnych modułowych technologii zapewniających łatwą budowę pojazdów i jednocześnie ułatwiony demontaż (zapewnienie łatwego i prostego rozdziału materiałów przy kasacji pojazdu).

Recykling tramwajów na etapie złomowania musi być wsparty rozwojem technologii zapewniających fizyczną likwidację wagonów (często zaprojektowanych kilkadziesiąt lat temu), przy jak najmniejszym negatywnym oddziaływaniu na środowisko naturalne.

Dobrze zorganizowany recykling wagonów tramwajowych jest opłacalną działalnością gospodarcza, tak ze względów ekonomicznych, społecznych jak i środowiskowych. Efekty ekonomiczne to przychody ze sprzedaży, jak i oszczędności, a efekty społeczne to nowe miejsca pracy i zwiększenie ochrony środowiska naturalnego.

W Polsce istnieje odpowiednia baza techniczna umożliwiająca odzysk pojazdów szynowych. Należy jednak liczyć się z inwestycjami w wyposażenie techniczne niezbędne do przeprowadzenia procesu recyklingu 
produktowego i materiałowego taboru szynowego, zwłaszcza pojazdów trakcyjnych.

W świetle rozszerzania się wśród krajowych przewoźników tramwajowych tendencji do złomowania pojazdów przez zewnętrzne firmy, należy wypracować metody i uregulować zasady wprowadzania do ponownego obiegu zespołów, elementów i części uzyskanych $\mathrm{w}$ procesie recyklingu przez te firmy.

Ponadto w przypadku złomowania wagonów tramwajowych przez firmy zewnętrzne należy:

- stworzyć sieć autoryzowanych i wyspecjalizowanych firm nowocześnie wyposażonych, w pełni respektujących wymogi ochrony środowiska,

- utworzyć ogólnokrajową bazę danych o przeprowadzonym recyklingu wagonów tramwajowych (bazę taką mogłaby prowadzać Izba Gospodarcza Komunikacji Miejskiej).

- wyeliminować możliwość ponownego wyprowadzania do użycia $w$ naprawach i modernizacjach wagonów, elementów i części wcześniej przeznaczonych do złomowania, przez wprowadzenie ogólnokrajowego systemu kontroli obrotu elementami, zespołami i częściami pochodzącymi $\mathrm{z}$ recyklingu wagonów tramwajowych.

\section{Literatura}

[1] Dyrektywa 2004/49/WE Parlamentu Europejskiego $i$ Rady z dnia 29 kwietnia 2004 r. w sprawie bezpieczeństwa kolei wspólnotowych oraz zmieniajaca dyrektywe Rady 95/18/WE w sprawie przyznawania licencji przedsiębiorstwom kolejowym, oraz dyrektywe 2001/14/WE w sprawie alokacji zdolności przepustowej infrastruktury kolejowej $i$ pobierania opłat za użtkowanie infrastruktury kolejowej oraz certyfikację $w$ zakresie bezpieczeństwa (Dyrektywa $w$ sprawie bezpieczeństwa kolei), Dz.U. L. 220 z 21.6.2004.

[2] Dyrektywa Parlamentu Europejskiego $i$ Rady 2000/53/WE z dnia 18 września 2000 r. w sprawie pojazdów wycofanych z eksploatacji, Dz. Urz. WEL 269 z dnia 21.10.2000 z późniejszymi zmianami.

[3] Dyrektywa 2006/12/WE Parlamentu Europejskiego $i$ Rady z dnia 5 kwietnia 2006 r. w sprawie odpadów (Dz. U. UEL 06.114.9 z dnia 27 kwietnia 2006 r.) z późniejszymi zmianami, zastępujaca Dyrektywę Rady $z$ dnia 15 lipca 1975 roku w sprawie odpadów (75/442/EWG).

[4] Gtówny Urząd Statyczny, Portal Informacyjny, www.stat.gov.pl

[5] Kodeks UIC 345 E. Specyfikacje środowiskowe dla nowych pojazdów szynowych. Międzynarodowy Zwiqzek Kolei UIC. Wydanie 1, czerwiec 2006.

[6] Komunikacja Miejska w Liczbach. Dane za lata

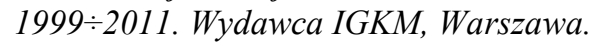

[7] Materiaty firmy Toyota.

[8] Materiaty i informacje firmy Alstom.

[9] Materiaty i informacje firmy Modertrans.

[10] Materiaty i informacje MPK Poznań.
[11] Materiaty $i$ informacje Spótki Tramwaje Warszawskie.

[12] Materiaty innych (nie wymiennych $z$ nazwy $w$ niniejszym wykazie „Literatura”) firm eksploatujacych tabor tramwajowy, przeprowadzajacych naprawy, modernizacje, likwidacje i złomowanie wagonów tramwajowych.

[13] Materiaty Instytutu Pojazdów Szynowych „TABOR” w Poznaniu.

[14] Materiaty Izby Gospodarczej Komunikacji Miejskiej $w$ Warszawie.

[15] Merkisz-Guranowska A., Stawecka H.: Recykling kolejowych wagonów towarowych na przykładzie Polski. Pojazdy Szynowe, 2012 nr 2.

[16] Merkisz-Guranowska A., Stawecka H.: Recykling pojazdów szynowych. Recykling, 2013 nr 3 (147).

[17] Raport roczny Tramwaje Warszawskie 2008. Warszawa 2009.

[18] Raport roczny Tramwaje Warszawskie 2010. Warszawa 2011.

[19] Roczniki Statystyczne Gtównego Urzędu Statystycznego.

[20] Rozporzqdzenie Ministra Infrastruktury $z$ dnia 12 października 2005 r. w sprawie ogólnych warunków technicznych eksploatacji pojazdów kolejowych, Dz.U. Nr 212 poz. 1771.

[21] Rozporzqdzenie Ministra Infrastruktury $z$ dnia 2 marca 2011 r. w sprawie warunków technicznych tramwajów $i$ trolejbusów oraz zakresu ich niezbędnego wyposażenia, Dz. U. Nr 65, poz. 344.

[22] Rozporzqdzenie Ministra Infrastruktury $z$ dnia 2 marca 2011 r. $w$ sprawie homologacji typu tramwajów i trolejbusów, Dz. U. Nr 65, poz. 345.

[23] Rozporzadzenie Ministra Infrastruktury $z$ dnia 28 stycznia 2011 r. w sprawie zakresu, warunków, terminów $i$ sposobu przeprowadzania badań technicznych tramwajów i trolejbusów oraz jednostek wykonujacych te badania, Dz. U. Nr 65, poz. 343.

[24] Soida K., Imielski T., Karpiński J., Dubiński K., Szylin M.: Od Warsztatów Przetwórczych do ALSTOM KONSTAL S.A. 135 lat zakladu. Wydawnictwo Emi-Press, Lódź 1999.

[25] Transport - Wyniki Działalności. Dane za poszczególne lata 2007:2011. Gtówny Urzad Statystyczny, Warszawa 2008.

[26] Transport Drogowy w Polsce w latach 2005-2009. Gtówny Urzad Statystyczny, Warszawa 2011.

[27] Ustawa z dnia 20 czerwca 1997 - Prawo o ruchu drogowym Dz. U. z 2005 r. Nr 108, poz.908, z późniejszymi zmianami.

[28] Ustawa z dnia 14 grudnia 2012 r. o odpadach, Dz.U. 2013 poz. 21 z późniejszymi zmianami.

[29] Zarzqdzenie nr 16/2007 z dnia 30 maja 2007 roku Prezesa Tramwajów Warszawskich Sp. z o.o. w m. st. Warszawie $w$ sprawie postępowania ze zbędnymi wagonami tramwajowymi.

[30] Zarzqdzenie $n r 20 / 98$ z dnia 21 września 1998 r. Dyrektora Tramwajów Warszawskich w sprawie postępowania ze zbędnymi wagonami tramwajowymi.

[31] Zarzqdzenie nr 6/96 z dnia 24.04.1996 r. Dyrektora Zakładu Budżetowego „Tramwaje Warszawskie” $w$ Warszawie $w$ sprawie zasad gospodarowania, ewidencji i obiegu dokumentów dotyczacych środków trwatych i pozostatych środków trwałych w użyaniu. 
[32] Zbiór dokumentów i obliczeń własnych autorów.

\section{Strony internetowe:}

[33] www.unife.org

[34] http://pl.wikipedia.org/wiki/Tramwaje_w_Bydgoszczy

[35] http://pl.wikipedia.org/wiki/Tramwaje_w_Chorzowie

[36] http://pl.wikipedia.org/wiki/Tramwaje_w_Cieszynie

[37] http://pl.wikipedia.org/wiki/Tramwaje_w_Cz\%C4\% 99stochowie

[38] http://pl.wikipedia.org/wiki/Tramwaje_w_Elblagu

[39] http://pl.wikipedia.org/wiki/Tramwaje_w_G\%C3\% B3rno\% C5\%9Bl\%C4\%85skim_Okrō $\overline{0} 4 \% 99 \mathrm{gu}$ Przemys\%C5\%82owym

[40] http://pl.wikipedia.org/wiki/Tramwaje_w_Gdańsku

[41] http://pl.wikipedia.org/wiki/Tramwaje_w_ Gorzowie Wielkopolskim

[42] http://pl.wikipedia.org/wiki/Tramwaje_w_Grudziadzu
[43] http://pl.wikipedia.org/wiki/Tramwaje_w_Kielcach

[44] http://pl.wikipedia.org/wiki/Tramwaje_w_Krakowie

[45] http://pl.wikipedia.org/wiki/Tramwaje_w_Eodzi

[46] http://pl.wikipedia.org/wiki/Tramwaje_w_Olsztynie

[47] http://pl.wikipedia.org/wiki/Tramwaje_w_Ptocku

[48] http://pl.wikipedia.org/wiki/Tramwaje_w_Poznaniu

[49] http://pl.wikipedia.org/wiki/Tramwaje_w_Sosnowcu

[50[ http://pl.wikipedia.org/wiki/Tramwaje_w_Szczecinie

[51] http://pl.wikipedia.org/wiki/Tramwaje_w_Toruniu

[52] http://pl.wikipedia.org/wiki/Tramwaje w- Warszawie

[53] http://pl.wikipedia.org/wiki/Tramwaje_we_Wroc\% C5\%82awiu

[54] http://pl.wikipedia.org/wiki/Konstal_105Na 